\title{
Comfrey (Symphytum Officinale. L.) and Experimental Hepatic Carcinogenesis: A Short-term Carcinogenesis Model Study
}

\author{
Maria Fernanda Pereira Lavieri Gomes ${ }^{1}$, Cristina de Oliveira Massoco ${ }^{2}$, \\ José Guilherme Xavier ${ }^{3}$ and Leoni Villano Bonamin ${ }^{1,3}$ \\ ${ }^{1}$ Laboratory of Veterinary Pathology, Faculty of Veterinary Medicine, University of Santo Amaro, ${ }^{2}$ Oncocell \\ biotecnologia LTDA and ${ }^{3}$ Laboratory of Pathology, Health Sciences Institute, University Paulista, São Paulo, Brazil
}

Comfrey or Symphytum officinale (L.) (Boraginaceae) is a very popular plant used for therapeutic purposes. Since the 1980s, its effects have been studied in long-term carcinogenesis studies, in which Comfrey extract is administered at high doses during several months and the neoplastic hepatic lesions are evaluated. However, the literature on this topic is very poor considering the studies performed under short-term carcinogenesis protocols, such as the 'resistant hepatocyte model' (RHM). In these studies, it is possible to observe easily the phenomena related to the early phases of tumor development, since pre-neoplastic lesions (PNLs) rise in about 1-2 months of chemical induction. Herein, the effects of chronic oral treatment of rats with $10 \%$ Comfrey ethanolic extract were evaluated in a RHM. Wistar rats were sequentially treated with $N$-nitrosodiethylamine (ip) and 2-acetilaminofluorene (po), and submitted to hepatectomy to induce carcinogenesis promotion. Macroscopic/microscopic quantitative analysis of PNL was performed. Non-parametric statistical tests (Mann-Whitney and $\chi^{2}$ ) were used, and the level of significance was set at $P \leq 0.05$. Comfrey treatment reduced the number of pre-neoplastic macroscopic lesions up to $1 \mathrm{~mm}(P \leq 0.05)$, the percentage of oval cells $(P=0.0001)$ and mitotic figures $(P=0.007)$, as well as the number of Proliferating Cell Nuclear Antigen (PCNA) positive cells $(P=0.0001)$ and acidophilic pre-neoplastic nodules $(P=0.05)$. On the other hand, the percentage of cells presenting megalocytosis $(P=0.0001)$ and vacuolar degeneration $(P=0.0001)$ was increased. Scores of fibrosis, glycogen stores and the number of nucleolus organizing regions were not altered. The study indicated that oral treatment of rats with $10 \%$ Comfrey alcoholic extract reduced cell proliferation in this model.

Keywords: Comfrey-hepatocarcinogenesis-phytotherapy-Symphytum sp

\section{Introduction}

The systematic study of plants normally used for consumption and that are able to modify the carcinogenesis process has greatly developed over recent years (1-6). Comfrey or Symphytum officinale (L.) (Boraginaceae) is a plant of fast growth, whose leaves and roots are used therapeutically since the XVI century, especially to

For reprints and all correspondence: Prof. Leoni Villano Bonamin, University Paulista, Setor de Pós Graduação, Rua Doutor Bacelar, 1212. 4th andar. CEP 04026-002, São Paulo, Brazil. Tel: 5511-55819291; Fax: 5511-55819291; E-mail: leonibonamin@gmail.com improve wound healing. Since the 1930s it has been used for animal feed, but this use has been prohibited in Australia and New Zealand $(5,7)$.

The toxic effects of Comfrey were described in the early 1980s and, since then, various pyrrolizidine alkaloids, such as lasiocarpine, lycopsamine, intermedine, symlandine, riddelliine and mainly symphytine have been identified (8-13). Chou and $\mathrm{Fu}$ (14) have recently determined that metabolic products of pyrrolizidine alkaloids, such as 6,7-dihydro-7-hydroxy-1-hydroxymethyl-5H-pyrrolizine (DHP)-derived DNA adducts, are formed in the liver of female F344 rats and can be related to its toxic effects. 
In long-term protocols, it was demonstrated that these active principles were hepatotoxic, mutagenic and carcinogenic (15). Mei and colleagues (16) observed that dietary comfrey resulted in marked changes in liver gene expression, body weight and mutation frequency. Hirono and colleagues (17) demonstrated that pyrrolizidine alkaloids induced hepatocellular adenoma and hemangiosarcoma with lung metastasis. Also, severe venousocclusive disease was present in the liver, characterized by hepatocyte swelling, formation of membrane blebs, endothelial proliferation and peri-venular hemorrhagic necrosis with deposition of reticulin $(18,19)$. Liver disease was also identified in cases of human chronic intoxication $(20,21)$, although some aspects of human toxicity of Comfrey has been recently revisited (22).

Among several demonstrations of carcinogenic effects of Comfrey, few studies have reported its anti-neoplastic effects (23). Even though, current information about its action in the initial stages of the carcinogenic processthat could be easily evidenced in short-term protocols - is very poor. Also, most studies of short-term hepatic carcinogenesis were performed using isolated active principles $(15,24)$.

Experimental models of liver carcinogenesis represent a simple and frequently used method for studying the genesis and evolution of neoplasms, because of the size and susceptibility of this organ to cancer $(25,26)$. Likewise, these short-term models-hepatectomy with treatment of animals with carcinogenic substancesare fast to perform, and rigid control of experimental conditions can be achieved without lack the in vivo particularities of carcinogenesis (27). The model used in the present work, resistant hepatocyte model (RHM), was first described by Solf and Faber (28). Thus, a single dose of $N$-nitrosodiethylamine (DEN) and repeated low doses of 2-acetilaminofluorene (AAF), both initiator agents, are administered concomitantly with hepatectomy, which acts as promotion stimulus. In this model, pre-neoplastic lesions (PNLs) can be seen in the liver as early as 5-10 days after hepatectomy. In the contrary, in long-term models, the prolonged treatment with carcinogens without surgery requires much more time to obtain the same lesions.

Herein, this model was used to study the effects of Comfrey extract on the development of early PNLs in liver.

\section{Methods}

\section{Animals}

Adult male Wistar rats weighting 200-250g were used. They were kept in conventional plastic cages (maximum: five rats per cage) maintained in an exclusive room and were exposed to a controlled light cycle (lights on from
6:30 AM to 6:30 PM) and temperature, which was fixed at $22 \pm 2{ }^{\circ} \mathrm{C}$. Food and drink were offered ad libitum. All animal care and maintenance procedures were performed according to guidelines of BPL (Brazilian GLP).

Ethical procedures were based on the Brazilian law 6638 (May 8, 1979) 'Normas para Prática DidáticoCientifica da Vivisseç̧ão de Animais', which is in accordance to the 'European Convention for the Protection of Vertebrate Animals used for Experimental and Other Scientific Purposes' (Strasbourg, March 18, 1986). Moribund rats were sacrificed for humane reasons, by deep anesthesia.

\section{Comfrey Extract Preparation}

One kilogram of Comfrey leaves harvested from FCAV Campus Jaboticabal (SP - Brazil) during the winter (July, in Brazil) was soaked with 11 of $93 \%$ ethanol and left to stand for 10 days at room temperature $\left(25 \pm 3^{\circ} \mathrm{C}\right)$. After this period, the mixture was filtered through conventional filter paper and processed by evaporation methods to obtain the ethanolic extract.

\section{Experimental Groups}

The $10 \%$ Comfrey extract was administered to all groups, three times a week, in a volume of $0.02 \mathrm{ml} / \mathrm{kg}^{-1}$ body weight, throughout all the experimental period. This extract concentration was chosen to reproduce the popular method of leaf preparation where toxic effects are described (11). Each group $(N=20$ at the beginning of the study) received the treatment by gavage, being the control treated with distilled water and the experimental group treated with the distilled water diluted extract.

Deaths are common in RHM and the rats that died during the study were not analyzed. At the end of the study, the number of surviving rats was eight in the control group and nine in the experimental group. The carcinogenesis protocol was as illustrated in the following scheme:

\begin{tabular}{|c|c|c|c|c|c|}
\hline $\begin{array}{l}\text { Day of } \\
\text { experiment }\end{array}$ & Zero & $15-17$ & 18 & 20,22 & 30 \\
\hline $\begin{array}{l}\text { Phase of } \\
\text { carcino- } \\
\text { genesis }\end{array}$ & Initiation & Initiation & Promotion & Initiation & - \\
\hline Procedure & Inoculation & $\begin{array}{c}\text { Inocula- } \\
\text { tion }\end{array}$ & $\begin{array}{l}\text { Hepatectomy } \\
\text { (30\% of the } \\
\text { liver mass) }\end{array}$ & $\begin{array}{l}\text { Inocula- } \\
\text { tion }\end{array}$ & Sacrifice \\
\hline Substance & DEN & $2 \mathrm{AAF}$ & - & $2 \mathrm{AAF}$ & - \\
\hline Dose & $\begin{array}{l}300 \mathrm{mg} / \mathrm{kg} \\
\quad \text { (intra- } \\
\text { peritoneal) }\end{array}$ & $\begin{array}{l}20 \mathrm{mg} / \mathrm{kg} \\
\quad \text { (gavage) }\end{array}$ & - & $\begin{array}{l}20 \mathrm{mg} / \mathrm{kg} \\
\quad \text { (gavage) }\end{array}$ & - \\
\hline
\end{tabular}

DEN, $N$-nitrosodiethylamine (SIGMA, St Louis, USA); diluted in $0.9 \%$ $\mathrm{NaCl}$; 2AAF, 2-acetilaminofluorene (SIGMA, St Louis, USA); diluted in corn oil. 
This model, including the hepatectomy technique, was adapted from Dagli and colleagues (29). All carcinogenic substances were handled in a chamber with controlled air output. All personnel involved wore appropriate masks provided with filters against powder and volatile substances, security glasses and double gloves. All material used for injections or gavage was discarded in appropriate boxes for hazardous specimens.

\section{Macroscopic Analysis}

After sacrifice, the number of PNLs on the liver surface was counted and classified according to diameter: (i) $<1 \mathrm{~mm}$, (2) around $1 \mathrm{~mm}$ and (3) $>1 \mathrm{~mm}$.

\section{Microscopic Analysis}

One $5 \mathrm{~mm}$ thick central slice was harvested from the left lateral lobe of the liver and fixed in Carnoy solution ( $3: 1: 6$ chloroform: glacial acetic acid: absolute alcohol) for $4 \mathrm{~h}$ (30). This material was processed by routine histological methods and stained with hematoxylin-eosin, $\mathrm{Ag}$-nucleolus organizing regions (NOR), Masson's trichrome and periodic acid Schiff (PAS). The immunohistochemistry procedures were also made from the same paraffin embedded material.

To perform the histometry of cell types and mitotic figures, photomicrographs of 5 pre-determined fields (top, bottom, laterals and center of the fragment) of each liver slice were obtained using a $200 \times$ objective. A grid with 200 points printed on transparent film was superimposed on the photographs and the number of points of intersection incident on each structure was recorded. The structures counted were: oval cells (hepatic steam cells), non-megalocytic and megalocytic hepatocytes (including multinucleated hepatocytes), degenerated (vacuolized) cells and mitotic figures (including typical and atypical mitosis).

PNLs were classified as 'acidophilic', 'mixed' and 'clear' patterns (29) and the total PNLs of each type per slice was counted directly from the microscope (Alphaphot, Nikon, Japan). Fibrosis was scored as follows, on the basis of Masson trichrome staining:

SCORE 0: without evidence of fibrosis

SCORE 1: discrete peri-portal fibrosis

SCORE 2: peri-portal and inter-nodular fibrosis

SCORE 3: peri-portal and inter-nodular fibrosis and capsule thickening

The same scoring method was used to quantify glycogen content of liver cells by PAS staining, as follows:

SCORE 0: without granules

SCORE 1: weak and diffuse granulation
SCORE 2: strong and multifocal granulation

SCORE 3: strong and diffuse granulation

Complementary slides were prepared for $\mathrm{AgNOR}$ protein identification using a silver staining method and for PCNA labeling by immunohistochemistry. The NORs were counted as described by Zaczek and colleagues (30). The number of NORs present in histological preparations reflects the quantity of active ribosomal genes and thus the proliferating status of tissues. This method is adequate to verify early stages of cell proliferation, including the interphase of the cell cycle, before the formation of mitotic figures.

The Proliferating Cell Nuclear Antigen (PCNA) positive cells counting was performed by submitting the slides to hot high pressure followed by overnight incubation with 1:100 anti-PCNA antibody (mouse anti-human, PC-10 clone, DAKO). The LSAB amplification system was also used. The slides were back stained with hematoxylin. Five microscopic fields were randomly chosen and 500 cells were counted for each slide. The PCNA method reveals the 'S phase cycle' positive cells, it means, cells in the early stages of duplication. Positive cells presented strongly nuclear reactivity. The numbers of positive and negative cells were recorded.

All the quantification procedures were done in blind.

\section{Statistical Analysis}

$F$-test to compare variances was first performed to verify the Gaussian distribution of the variables, as a result of which non-parametric Mann-Whitney tests (PNL, NOR, fibrosis and glycogen granules counting) and $\chi^{2}$-test (cell counting) were used. The ' $P$ ' values were fixed at $P \leq 0.05$.

\section{Results}

\section{Macroscopic Pre-neoplastic Nodules Counting}

PNL counting on the liver surface is represented in Fig. 1. The number of nodules measuring $1 \mathrm{~mm}$ in diameter or less was significantly reduced in Comfrey treated rats, compared to control.

\section{Microscopic Morfometry}

The cell type percentages are given in Table 1. The experimental group showed significant increase in the percentage of megalocytic and vacuolized cells and decrease in oval cells, PCNA positive cells and mitosis, compared to control.

The number of NORs per field and the scores for fibrosis and glycogen granulation on liver slides, respectively stained by Masson trichrome and PAS, did not 


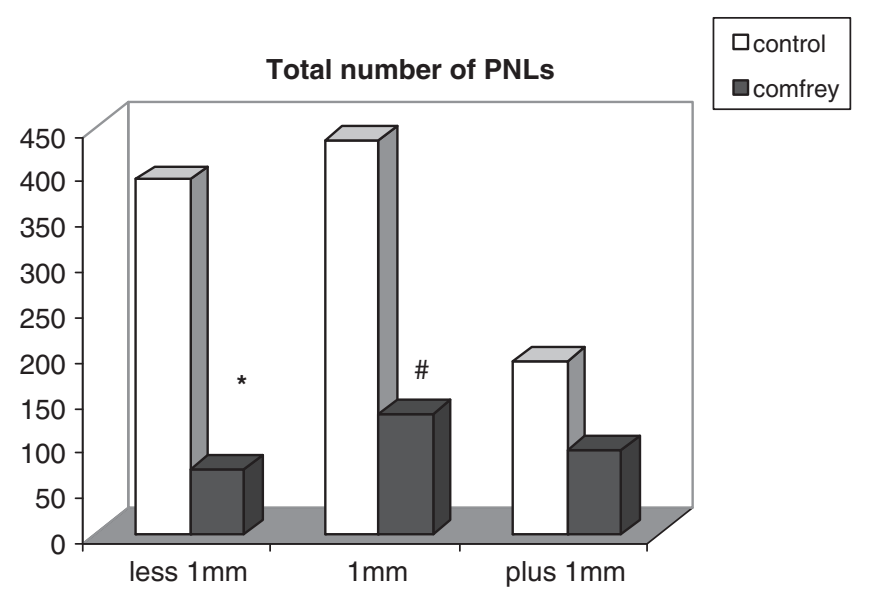

Figure 1. Total number of pre-neoplastic lesions (PNL) counted on the surface of livers of rats undergoing the 'resistant hepatocyte' model. Values represent the total number of nodules in all animals; experimental rats were treated with $10 \%$ Comfrey extract, po. *Mann-Whitney test, $P=0.0464(\mathrm{U}=57.000)$; ${ }^{*}$ Mann-Whitney test, $P=0.0037(\mathrm{U}=65.000)$.

Table 1. Histometry data: percentage of points corresponding to each structure observed in photomicrographs of livers from rats undergoing the 'resistant hepatocyte' model

\begin{tabular}{lcc}
\hline Structures counted & Control $(\%)$ & Experimental $(\%)$ \\
\hline Megalocytic cells & 7.88 & $11.11^{\# \#}$ \\
Non-megalocytic cells & 55.4 & 64.95 \\
Oval cells & 34.24 & $19.20^{\#}$ \\
Vacuolized cells & 1.68 & $4.31^{\# \#}$ \\
Mitotic figures & 0.80 & $0.43^{*}$ \\
PCNA positive cells & 13.86 & $5.13^{* *}$ \\
Total & 100 & 100 \\
\hline
\end{tabular}

Experimental rats were treated with $10 \%$ Comfrey extract, po. $* \chi^{2}=12.226 ; \quad P=0.0005 ; \quad{ }^{\#} \chi^{2}=6.949 ; \quad P=0.0084 ; \quad{ }^{\#} \chi^{2}=364.86$; $P<0.0001 ; * * \chi^{2}=65.523 ; P<0.0001$.

Table 2. Histometry data: Number of pre-neoplastic lesions (PNLs) per slice defined as: 'acidophilic', 'mixed' or 'clear cell' nodules

\begin{tabular}{lll}
\hline PNL & Control $(N=8)$ & Experimental $(N=9)$ \\
\hline Acidophilic cells & $7.87 \pm 14.31^{\mathrm{a}}$ & $2.11 \pm 5.97^{* *}$ \\
Mixed & $28.37 \pm 23.86$ & $11.00 \pm 14.26$ \\
Clear cells & $1.50 \pm 2.390$ & $1.88 \pm 2.571$ \\
\hline
\end{tabular}

Experimental rats were treated with $10 \%$ Comfrey extract, po.

${ }^{a}$ Values represent mean \pm standard deviation.

**Mann-Whitney test, $P=0.05(\mathrm{U}=56.0)$.

This cell behavior follows the sequence: clear/mixed/acidophilic/ basophilic nodules, according to their aggressiveness (see text).

differ between groups. Table 2 shows the number of PNL according to nodule classification. The experimental group presented significant reduction of acidophilic nodules compared to control.
In short, the results showed a clear protective effect of Comfrey extract on the early stages of induced hepatic carcinogenesis.

\section{Discussion}

In this work, the putative effects of Comfrey extract on the initial stages of neoplastic development were tested. Both, macroscopic and microscopic criteria were considered to evaluate its capacity to change proliferation parameters.

Macroscopically, the number of PNLs was reduced by treatment with Comfrey extract, mainly those measuring $1 \mathrm{~mm}$ or less. This particular result suggests that Comfrey extract was able to modulate the early stages of PNL development. These macroscopic findings were supported by the microscopic observations. The increase of the percentage of megalocytic and vacuolized liver cells, associated with the decrease of the percentage of oval cells, PCNA-positive cells, mitotic figures and the number of acidophilic nodules, converge to the antiproliferation hypothesis. Considering the cell phenotype, the pre-neoplastic nodules are classified according to the following aggressiveness indicators: clear (vacuolized/ degenerated) cells, mixed (acidophilic and vacuolized cells in the same nodule) cells, acidophilic (intense protein synthesis) cells and basophilic (intense proliferation activity) cells.

It is important to note that oval cells and acidophilic nodules are typical manifestations of early tumor establishment (29). Thus, their reduction also points toward to a qualitative anti-neoplastic property.

Adding to the earlier described findings, the increase of megalocytosis percentage, the decrease of PCNA-positive cells and cells showing mitosis phenotype also suggest anti-mitotic effects. Some authors consider megalocytosis as a 'frustrated mitosis', in which the cell prepares to divide but telophase does not occur (31). This phenotype has been described by other authors in liver models, especially those associated with the effects of pyrrolizidine alkaloids (32), also present in Comfrey extracts (14, 33-35). It is known that chronic ingestion of pyrrolizidine alkaloids by cattle leads to peri-portal fibrosis and bile duct proliferation (33), phenomena related to the proliferation of oval cells. Herein, the reduction on the percentage of these cells reinforces the evidence of anti-mitotic effects (36).

This convergence of results is according the previous studies in which the anti-mitotic effects of pyrrolizidine alkaloids are preponderant over the carcinogenic ones in short-term experimental procedures (37).

The negative result of AgNOR counting may be related to the low degree of sensitivity of this test.

Although scores of glycogen cell stores were not modified, vacuolized hepatocytes were more numerous 


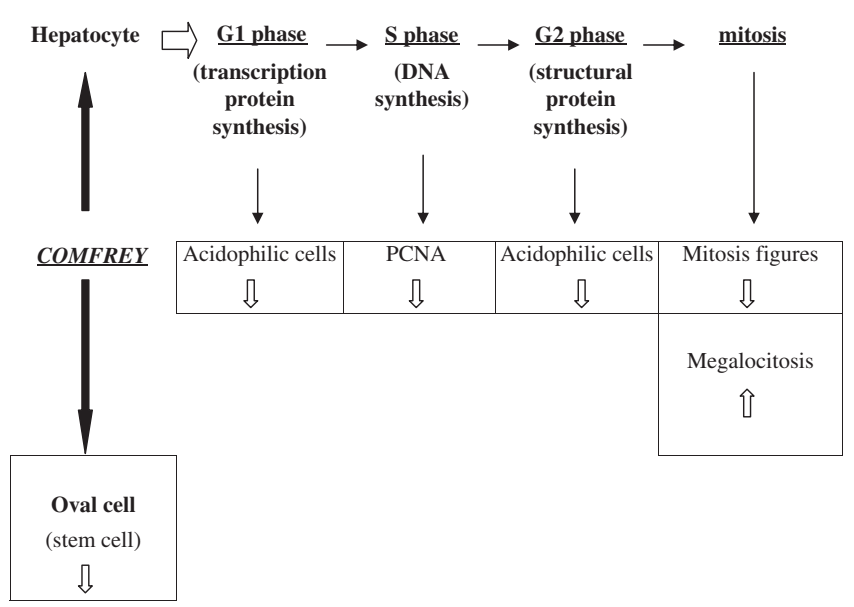

Figure 2. Hypothetic framework showing the putative action of Comfrey extract upon several steps of cell proliferation process.

in treated rats, what could be related to some oxidative toxic effects of Comfrey (36). In fact, degenerative hepatocyte lesions induced by this plant have been described previously $(18,19)$. The study of Comfrey and other herbs largely used as complementary medicine deserves more specific studies, since plant extracts are chemically diverse and may be able to modulate several metabolism steps simultaneously. Nowadays, some gene expression studies are on the focus of scientific interest for better understanding their molecular mechanisms (38).

To delineate a general hypothesis about the putative mechanism of action of Comfrey extract in this model, a resumed framework is presented in the Fig. 2, showing how the mitotic process could be suppressed at several steps, at the same time.

In conclusion, the present findings can contribute to understand a very particular and under explored Comfrey pharmacological activity, since the treatment of rats with its extract seems to protect them from early development of pre-neoplastic liver lesions, by inhibiting cell proliferation and modulating atypical phenotype.

\section{Acknowledgements}

We thank Vilma Felix dos Santos for preparing the slides, Dr Fernando S. Moreno and Dr Maria Lucia Zaidan Dagli for suggestions about the experimental model, Dr Josmar S. Arrais de Matos, UNISA Pro-rector for Research and Dr Godofredo C. Genofre Netto, UNISA Research Director, for support.

\section{References}

1. Chung FL. The prevention of lung cancer induced by a tobaccospecific carcinogen in rodents by green and black tea. Proc Soc Exp Biol Med 1999;220:244-8.

2. Klepser TB, Klepser ME. Unsafe and potentially safe herbal therapies. Am J Health Syst Pharm 1999;56:125-38.
3. Tanida N, Kawaura A, Takahashi A, Sawada K, Shimoyama T. Suppressive effect of wasabi (pungent Japanese spice) on gastric carcinogenesis induced by MNNG in rats. Nutr Cancer 1991;16:53-8.

4. Waladkhani AR, Clemens MR. Effect of dietary phytochemicals on cancer development (review). Int J Mol Med 1998;1:747-53.

5. Lewis JH. Drug-induced liver disease. Curr Opin Gastroenterol 2002;18:307-13

6. Altamirano JC, Gratz SR, Wolnik KA. Investigation of pyrrolizidine alkaloids and their $\mathrm{N}$-oxides in commercial comfrey-containing products and botanical materials by liquid chromatography electrospray ionization mass spectrometry. JAOAC Int 2005;88:406-12.

7. Saito ML, Oliveira F. Confrei: Virtudes e problemas. Rev Bras Farmacogn 1986;1:74-85 [Portuguese].

8. Kim NC, Oberlies NH, Brine DR. Isolation of symlandine from the roots of common comfrey (Symphytum officinale) using countercurrent chromatography. J Nat Prod 2001;64:251-3.

9. Mattock AR. Toxic pyrrolizidine alkaloids in Comfrey. Lancet 1980;1:1136-37.

10. Palmer S, Matthews RA. The role of non-nutritive dietary constituents in carcinogenesis. Surg Clin North Am 1986;66:891-915.

11. Stickel F, Seitz HK. The efficacy and safety of comfrey. Public Health Nutr 2000;3:501-8.

12. Williams L, Chou MW, Yan J. Toxicokinetics of riddelliine, a carcinogenic pyrrolizidine alkaloid, and metabolites in rats and mice. Toxicol Appl Pharmacol 2002;182:98-104.

13. Mei N, Guo L, Fu PP, Heflich RH, Chen T. Mutagenicity of comfrey (Symphytum officinale) in rat liver. $\mathrm{Br} J$ Cancer 2005;92:873-5

14. Chou MW, Fu PP. Formation of DHP-derived DNA adducts in vivo from dietary supplements and Chinese herbal plant extracts containing carcinogenic pyrrolizidine alkaloids. Toxicol Ind Health 2006;22:321-7.

15. Laconi E, Sarma DS, Pani P. Transplantation of normal hepatocytes modulates the development of chronic liver lesions induced by a pyrrolizidine alkaloid, lasiocarpine. Carcinogenesis 1995;16:139-42.

16. Mei N, Guo L, Zhang L, Shi L, Sun YA, Fung C, et al. Analysis of gene expression changes in relation to toxicity and tumorigenesis in the livers of Big Blue transgenic rats fed comfrey (Symphytum officinale). BMC Bioinformatics 2006;7 (Suppl 2): S16.

17. Hirono I, Mori H, Haga M. Carcinogenic activity of Symphytum officinale. J Natl Cancer Inst 1978;61:865-9.

18. Yeong ML, Clark SP, Waring JM. The effects of comfrey derived pyrrolizidine alkaloids on rat liver. Pathology 1991;23:35-8.

19. Yeong ML, Wakefield SJ, Ford HC. Hepatocyte membrane injury and bleb formation following low dose comfrey toxicity in rats. Int $J$ Exp Pathol 1993;74:211-7.

20. Ridker PM, Ohkuma S, McDermott WV, Trey C, Huxtable RJ. Hepatic venocclusive disease associated with the consumption of pyrrolizidine-containing dietary supplements. Gastroenterology 1985;88:1050-4.

21. Yeong ML, Swinburn B, Kennedy M. Hepatic veno-occlusive disease associated with comfrey ingestion. J Gastroenterol Hepatol 1990;5:211-4.

22. Rode D. Comfrey toxicity revisited. Trends Pharmacol Sci 2002;23:497-9.

23. Hirono I. Induction of tumors in rats by senkirkine and symphytine. J Natl Cancer Inst 1979;63:469-71.

24. Hayes MA, Roberts E, Farber E. Initiation and selection of resistant hepatocyte nodules in rats given the pyrrolizidine alkaloids lasiocarpine and senecionine. Cancer Res 1985;45:3726-34.

25. Farber E, Cameron R. The sequential analysis of cancer development. Adv Cancer Res 1980;31:125-226.

26. Sasaki M, Yoshida T. Experimentelle Erzeungung des Libercarcinoms duich Fütterung mit-o-Amidoa Zototuol. Virchows Archiv A (Pathological Anatomy) 1935;295:175-200.

27. Farber E, Sarma DSR. Hepatocarcinogenesis: a dynamic cellular perspective. Lab Invest 1987:1:4-22.

28. Solf D, Faber E. New principle for the analysis of chemical carcinogenesis. Nature 1976;263:701-3.

29. Dagli MLZ, Guerra JL, Sinhorini IL, Wu TS, Rizzi MBSL, Penteado MVC, et al. Beta-carotene reduces the ductular (oval) cell 
reaction in the liver of Wistar rats submitted to the resistant hepatocyte model of carcinogenesis. Pathology 1998;30:259-66.

30. Zaczek M, Dabros E, Maciejowski J, Szot W. Identification and assessment of nucleolar organizer regions (NORs) - technical problems. Pat Pol 1994;45:35-8.

31. Carlton WW, Mac Gavin MD. Patologia Veterinária Especial de Thomson, 2nd edn. Porto Alegre: ArtMed, 1998 [Portuguese].

32. Laconi S, Pani P, Pillai S, Sarma DSR, Laconi E. A growthconstrained environment drives tumor progression in vivo. Proc Natl Acad Sci USA 2001;98:7806-11.

33. Laconi E. Liver regeneration in response to partial hepatectomy in rats treated with retrosine: a kinetic study. J Hepatology 1999;31:1069-74.
34. Behinger C, Abel G, Roder E, Neuberger V, Goggelmann W. Studies on the effect of an alkaloid extract of Symphytum officinale on human lymphocyte cultures. Planta Med 1989;55:518-22.

35. Kim HY, Stermitz FR, Coulombe RA. Pyrrolizidine alkaloidinduced DNA-protein cross links. Carcinogenesis 1995;16:2691-7.

36. Olinescu A, Manda G, Neagu M. Action of some proteic and carbohydrate components of Symphytum officinale upon normal and neoplastic cells. Roum Arch Microbiol Immunol 1993;52:73-80.

37. Jubb KVF, Kennedy PC, Palmer N. Pathology of Domestic Animals, 4th edn. San Diego: Academic Press, 1993.

38. Chavan P, Joshi K, Patwardhan B. DNA microarrays in herbal drug research. Evid Based Complement Alternat Med 2006;3:447-57.

Received June 10, 2005; accepted September 25, 2007 


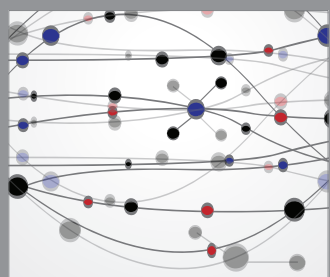

The Scientific World Journal
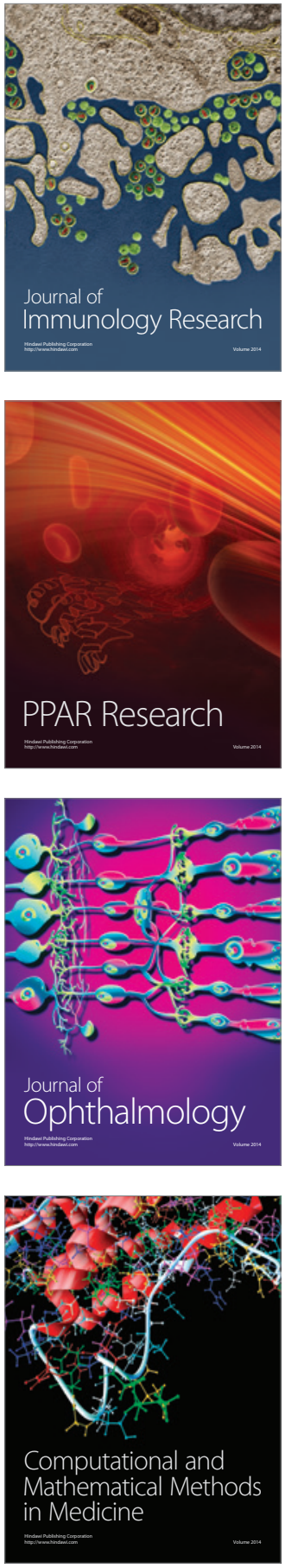

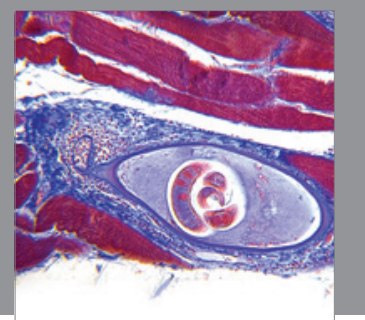

Gastroenterology

Research and Practice
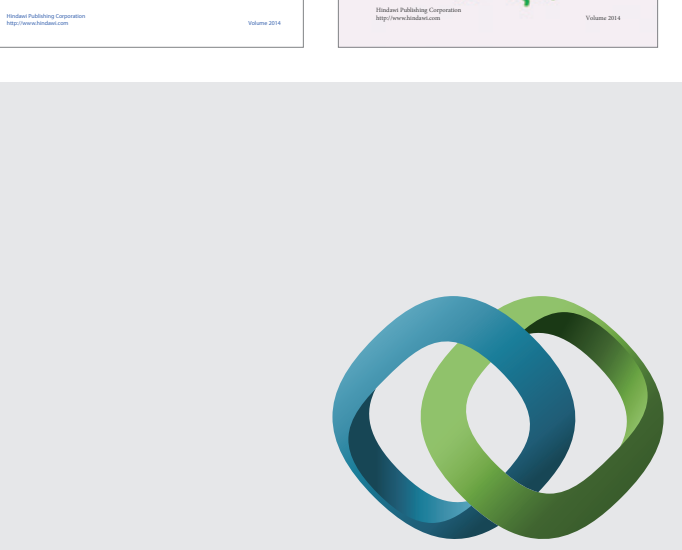

\section{Hindawi}

Submit your manuscripts at

http://www.hindawi.com
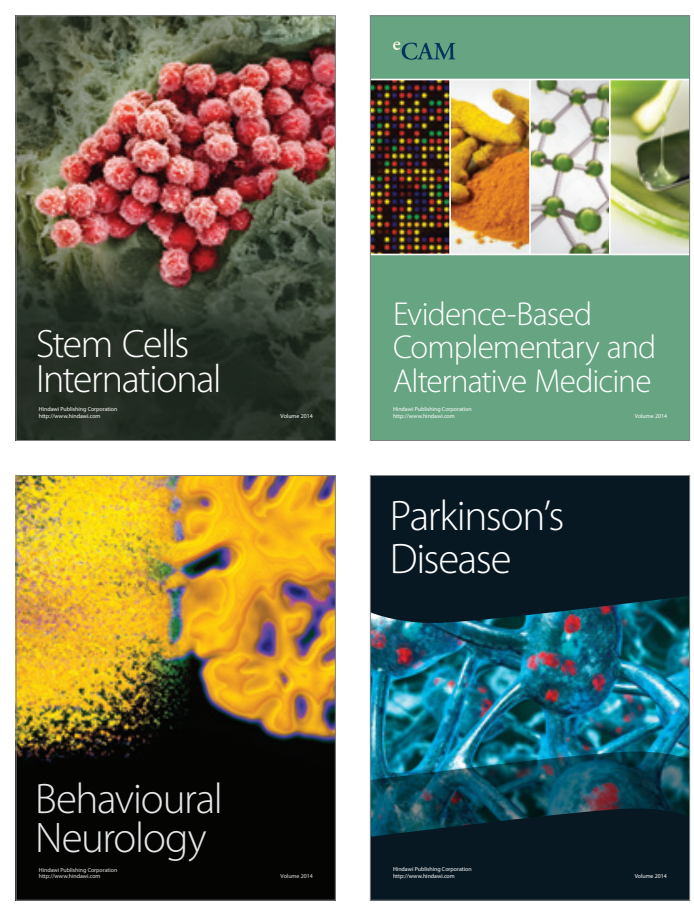

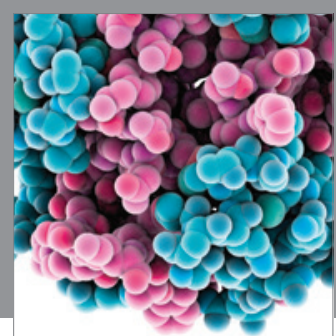

Journal of
Diabetes Research

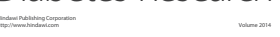

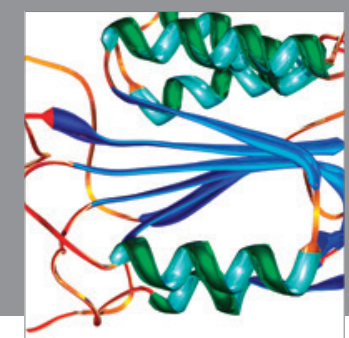

Disease Markers
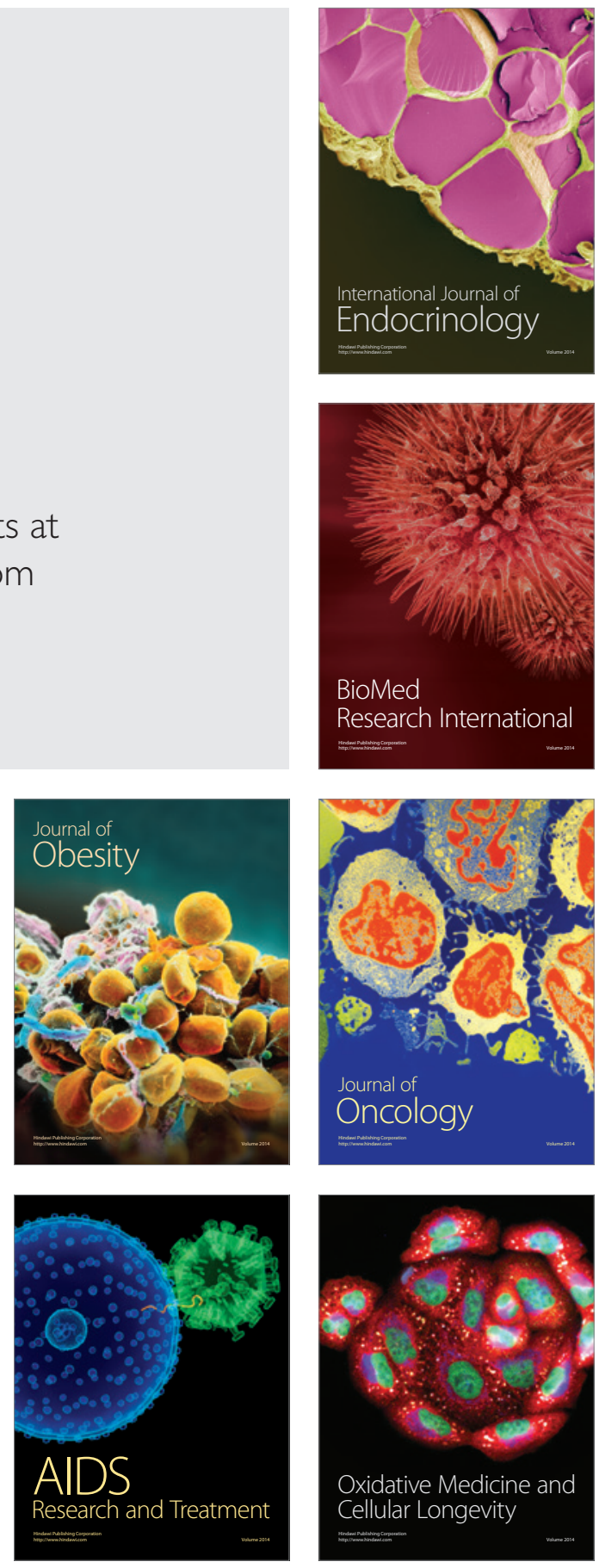